\title{
Território Café do Cerrado: transformações na estrutura produtiva e seus impactos sobre o pessoal ocupado
}

\author{
Antonio César Ortega ${ }^{1}$ \\ Clesio Marcelino Jesus ${ }^{2,3}$
}

\begin{abstract}
Resumo: O desenvolvimento da agricultura brasileira ao longo do século XX e início deste século XXI provocou grandes transformações no processo produtivo de diversas cadeias agropecuárias. Neste contexto, o Cerrado Mineiro merece destaque particular, pois se consolidou como uma das regiões cafeicultoras mais modernas do país, com a adoção de um conjunto de inovações tecnológicas, cujo resultado foi a obtenção de elevada produtividade e qualidade do café. Entretanto, para se alcançar tal grau de desenvolvimento tecnológico, a estrutura produtiva passou por grandes transformações desde o início dos anos 70 até 2000, inclusive no que diz respeito às relações de trabalho. O objetivo deste artigo é apontar como se deram essas transformações, qual o impacto sobre a produção e o emprego, bem como sobre a organização dos cafeicultores em torno do fortalecimento da cadeia do café. Para alcançar esses objetivos, foi realizada revisão bibliográfica de trabalhos de especialistas da área, além da utilização de dados dos censos agropecuários de 1970 a 2006 e pesquisa de campo junto a produtores e lideranças representativas dos cafeicultores, pesquisadores agronômicos, técnicos de assistência técnica e empresas líderes na comercialização de insumos e equipamentos. Concluiu-se que o processo de modernização da atividade do café no Cerrado Mineiro provocou impactos significativos na ampliação da área produtiva, na produtividade, na geração de novos postos de trabalho em atividades mais qualificadas e redução das menos qualificadas.
\end{abstract}

Palavras-chave: Agricultura, Café do Cerrado, Inovações tecnológicas, Emprego rural.

1 Professor associado III do Instituto de Economia da Universidade Federal de Uberlândia. E-mail: acortega@ufu.br

2 Doutorando em Economia pelo PPGE/IE/UFU. E-mail: clesiomj@gmail.com

3 Agradecemos ao CNPq e à Fapemig pelos financiamentos que viabilizaram essa pesquisa, cujos resultados estão parcialmente apresentados aqui. 
772 - Território Café do Cerrado: transformações na estrutura produtiva e seus impactos sobre o pessoal ocupado

Abstract: The development of the Brazilian agriculture over the twentieth century and at the beginning of this century led to major changes in the production process of different agricultural chains. Coffee in the Cerrado Mineiro region deserves special attention in this context; therefore, it has been established as one of the most modern in Brazil, with the adoption of a set of technological innovations, which has resulted in high yield and quality of the coffee. However, to reach this situation, the production structure has changed significantly since the early 1970's until 2000. This study aims to point out how such transformations occurred and the consequent impacts on production as well the relations of production and employment. To reach these objectives, data from agricultural census from 1970 to 2006 was used, along with specialized work and field research with the application of semi-structured questionnaires with a representative leadership (from coffee growers and workers) and leading companies in the market of inputs and coffee equipment. The conclusion is that the modernization process of the coffee activity in the Cerrado Mineiro region has caused significant impacts on the generation of employed people, generating new activities and a demand for a workforce which is more qualified.

Key-words: Agriculture, Coffee from Cerrado,Technological innovations, Rural job.

Classificação JEL: R11, R23, R52.

\section{Introdução}

Quando se analisa o desenvolvimento da agricultura brasileira ao longo do século XX e início deste século XXI as grandes transformações no processo produtivo de diversas cadeias agropecuárias merecem destaque. De uma agropecuária tradicional, pouco intensiva em capital, passou-se a verificar a consolidação de uma agricultura intensiva em tecnologia, ainda que não tenha sido disseminada de forma homogênea entre os produtores, os produtos e regiões brasileiras.

O café do Cerrado Mineiro ${ }^{4}$ merece destaque particular nesse contexto, pois, ao ser introduzido na região, tem se consolidado com a adoção de um conjunto

4 Nesse território, foram priorizados os 55 municípios produtores de café que, por meio de nove associações, formam o Conselho das Associações de Cafeicultores do Cerrado (Caccer). Estes municípios são: Abadia dos Dourados, Araguari, Arapuá, Araxá, Bambuí, Bonfinópolis, Buritis, Buritizeiro, Campos Altos, Canápolis, Carmo do Paranaíba, Cascalho Rico, Conquista, Coromandel, Córrego Danta, Cruzeiro da Fortaleza, Douradoquara, Estrela do Sul, Grupiara, Guarda Mor, Guimarânia, Ibiá, Indianopolis, Iraí de Minas, João Pinheiro, Lagamar, Lagoa Formosa, Matutina, Medeiros, Monte Alegre, Monte Carmelo, Nova Ponte, Paracatu, Patos de Minas, Patrocínio, Pedrinópolis, Perdizes, Pratinha, Presidente Olegário, Rio Paranaíba, 
de inovações tecnológicas que levou especialistas do setor a classificarem sua produção como uma das mais modernas do país, com elevada produtividade e qualidade da bebida.

Esse processo produtivo adotado na cafeicultura do Cerrado Mineiro, intensivo em capital, provocou, ainda, transformações importantes nas relações de trabalho, com impacto na estrutura produtiva e sobre o emprego. Nesse artigo, portanto, serão analisadas as transformações ocorridas na estrutura produtiva, em função da adoção de inovações biológicas, mecânicas, físico-químicas e agronômicas, que afetaram as relações de trabalho e o emprego rural.

Para tanto, foi realizada a revisão bibliográfica de trabalhos de especialistas da área, com utilização dos dados dos censos agropecuários de 1970 a 2006 e pesquisa de campo, além da aplicação de questionários semiestruturados junto a produtores e lideranças representativas dos cafeicultores, pesquisadores agronômicos, técnicos de assistência técnica e empresas líderes na comercialização de insumos e equipamentos.

Conclui-se que as transformações recentes na cafeicultura do Cerrado Mineiro provocaram impactos significativos. Ampliou-se a área produtiva, elevou-se a produtividade, o que impactou nas relações de trabalho, com geração de postos de trabalho que requerem trabalhadores mais qualificados, ainda que temporários, e com a introdução de empresas prestadoras de serviços agrícolas.

\section{Metodologia do trabalho}

Esse artigo é resultado de um projeto de pesquisa cuja metodologia procura combinar análises qualitativas e quantitativas. Primeiramente, foi feita uma revisão bibliográfica sobre a evolução do processo de consolidação da cafeicultura do Cerrado Mineiro, a partir de documentos oficiais, de material de divulgação das organizações representativas da cafeicultura do Cerrado Mineiro e de trabalhos acadêmicos de especialistas.

Em seguida, questionários em universo representativo para aprofundamento do estudo foram aplicados. Dessa maneira, "recorre-se à entrevista, a partir da necessidade de obter dados que não podem ser encontrados em registros e fontes documentais e que podem ser fornecidos por certas pessoas" (CERVO, BERVIAN e DA SILVA, 2007, p. 51).

As entrevistas foram direcionadas a diferentes segmentos da cadeia produtiva. Assim, foram entrevistados produtores rurais, empresários dos

Romaria, Sacramento, Santa Juliana, Santa Rosa da Serra, São Gonçalo do Abaeté, São Gotardo, Serra do Salitre, Tapira, Tiros, Tupaciguara, Uberaba, Uberlândia, Unaí, Varjão de Minas e Vazante. 
Território Café do Cerrado: transformações na estrutura produtiva e seus impactos sobre o pessoal ocupado

setores industriais e de serviços, particularmente de empresas terceirizadoras das atividades de mecanização. Foram entrevistados, ainda, representantes e membros de associações de produtores, de cooperativas, de sindicatos e do Conselho das Associações dos Cafeicultores. Por último, foram entrevistados técnicos e pesquisadores de órgãos públicos que apoiam a atividade cafeeira.

Para a realização dessas entrevistas, diferentes modelos de questionários previamente estruturados, que serviram de roteiro para as entrevistas gravadas, foram utilizados. Por meio dessa metodologia, de obtenção de informações utilizando fontes orais, foi possível registrar experiências e avaliações críticas de diferentes atores sociais territoriais. Para a seleção dos entrevistados, líderes e produtores típicos ${ }^{5}$, privilegiou-se a heterogeneidade.

Por fim, foi realizado um estudo quantitativo/descritivo de investigação com a finalidade de delinear e analisar as principais características de fatos ou fenômenos, capazes de fornecer dados para a verificação da hipótese de modernização da atividade cafeeira. Para tanto, foram explorados os dados secundários dos censos agropecuários entre 1970 e $2006^{6}$ por meio de uma análise temporal.

O objetivo, portanto, foi buscar, com base nos censos agropecuários, uma fonte segura de dados para análise da cafeicultura do Cerrado Mineiro. Para tanto, foram selecionadas variáveis fundamentais para a compreensão da evolução dessa cafeicultura, como o número de máquinas, a área produtiva, número de pessoas empregadas, área ocupada com lavouras, entre outras. Desse modo, os dados foram sistematizados, analisados em diálogo com a teoria, de acordo com os objetivos delineados.

\section{A introdução do café no Cerrado Mineiro e suas inovaçổes tecnológicas}

A política de modernização da cafeicultura brasileira iniciou-se ainda na década de 1960, com o objetivo de erradicar os cafeeiros de baixa produtividade. Essa foi uma década de superprodução, obtida por meio da expansão da área cultivada. O lema adotado na ocasião era "Renovar para Salvar", em uma

5 Utilizando-se a noção de tipos ideais weberianos, foram selecionados produtores rurais cuja produção é altamente tecnificada, assim como aqueles que não vêm conseguindo incorporar todas as inovações disponíveis, como é o caso dos agricultores familiares que possuem propriedades de elevada declividade e que não podem introduzir a colheita mecânica.

6 É importante ressaltar que as mudanças de metodologia para cada um dos censos agropecuários realizados no período foram consideradas. 
política de desestímulo ao plantio de novos cafezais e seleção dos de maior produtividade e qualidade.

Em 1969, com a ocorrência de fortes geadas nas regiões produtoras, agregou-se outro objetivo à produção cafeeira nacional: impedir que oscilações tão bruscas comprometessem a exportação e, como consequência, a entrada de divisas. Foi nesse momento que uma política de reordenação territorial ganhou corpo e o Cerrado Mineiro passou a ser a região prioritária de incentivo à cafeicultura nacional. Foi implantado o Plano de Renovação e Revigoramento de Cafezais (PRRC), com iniciativa do Instituto Brasileiro do Café (IBC) e o Grupo Executivo de Racionalização da Cafeicultura (Gerca), com recursos do Tesouro Nacional e do Banco do Brasil, entre outros agentes financeiros.

O PRRC visava a elevação da produção do café e de sua produtividade, por meio da implantação de cultivos racionais em áreas climaticamente favoráveis, com menor propensão a geadas. Assim, boa parte dos municípios das microrregiões de Paracatu, Pirapora, Uberlândia, Patrocínio, Patos de Minas, Uberaba, Araxá e Piuí, no estado de Minas Gerais (que aqui é denominado de Cerrado Mineiro ${ }^{7}$ ), foi contemplada, direta ou indiretamente, com os recursos do PRRC, com destaque para as microrregiões Uberlândia, Patrocínio e Patos de Minas. Intensificou-se a expansão da cafeicultura em uma região pouco tradicional no cultivo da cultura, o que culminou, nos anos 2000, em uma das atividades cafeeiras mais desenvolvidas do país.

Destacam-se as atividades da Embrapa (Empresa Brasileira de Pesquisa Agropecuária), IBC (Instituto Brasileiro do Café), Epamig (Empresa de Pesquisa Agropecuária de Minas Gerais) e IAC (Instituto Agronômico de Campinas). Tais órgãos contribuíram nas análises de viabilidade técnica e econômica e desenvolveram pesquisas de adaptação da cultura à região, criando variedades próprias que propiciavam a aplicação de métodos e práticas culturais que favoreciam as qualidades físico-químicas do solo (BDMG, 1989, p. 230). Além disso, a cafeicultura contou com o apoio financeiro de importantes programas governamentais para produção no Cerrado brasileiro.

A atividade cafeeira no Cerrado Mineiro cresceu em virtude dos incentivos proporcionados por Minas Gerais. Depois de duas décadas de crescimento (1970-1980), na década de 1990, enfrentou forte revés, quando o governo brasileiro retirou-se dos Acordos Internacionais do Café e extinguiu o IBC, em um contexto de forte desregulamentação do setor. Como uma das reações para o enfrentamento dessa nova realidade, cafeicultores do Cerrado Mineiro mobilizaram-se para enfrentar essa nova situação, fundando associações de

7 É importante esclarecer que a abrangência das terras de Cerrado em Minas Gerais é muito maior do que as que se concentram nessas microrregiões. $\mathrm{O}$ uso da expressão "Cerrado Mineiro", nesse sentido, está ligado ao fato de que é nessas microrregiões que se concentra a produção de café em terras de Cerrado no estado mineiro. 
Território Café do Cerrado: transformações na estrutura produtiva e seus impactos sobre o pessoal ocupado

produtores. Da união dessas associações, que emergiram nos municípios-polo da região cafeeira, surgiu o Conselho das Associações de Cafeicultores do Cerrado (Caccer), cujo objetivo principal é incentivar a produção de café de qualidade, diferenciada por origem e padronizada. Seus associados têm direito a obter o selo de qualidade do produto e certificação de origem. As associações se encarregam, ainda, da comercialização do produto no mercado interno e externo, além de exercerem o papel de representação político-sindical (ORTEGA, 1997).

O mapa da Figura 1 apresenta a localização territorial das associações que congregam os 55 municípios do Cerrado Mineiro em Minas Gerais. Na parte cinza da figura, tem-se o mapa do Brasil, com a localização de Minas Gerais, e sobreposto a esse estado, o território de café do Cerrado8.

Figura 1. Localização das associações dos cafeicultores na região do Cerrado Mineiro.

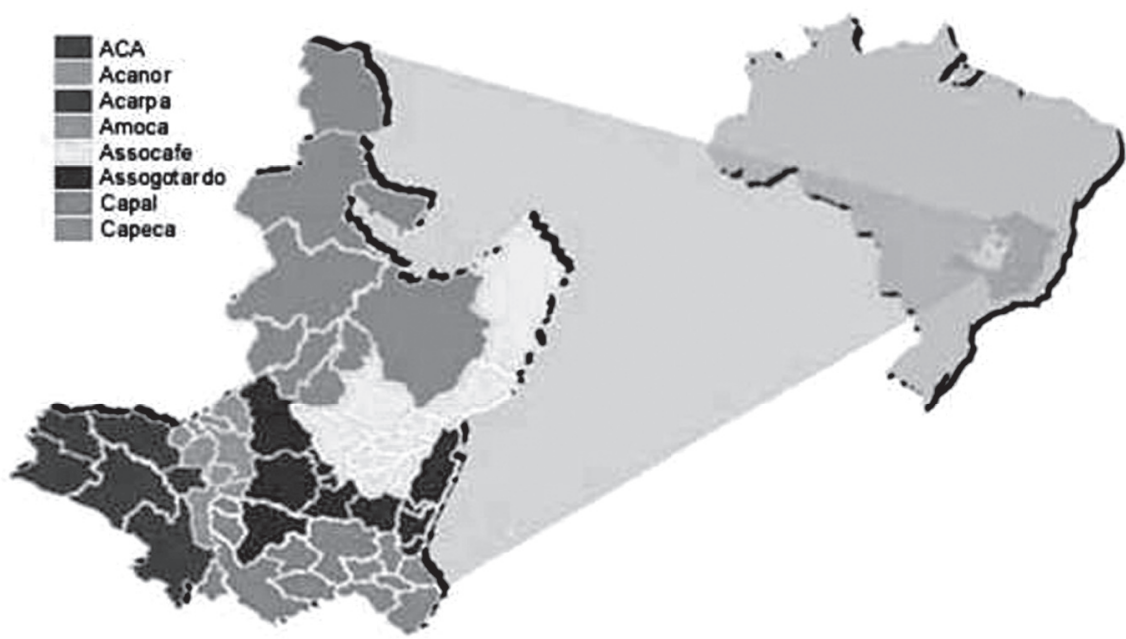

Fonte: Café do Cerrado. Disponível em http://www.cafedocerrado.org.br. Acesso em março de 2010.

8 Cada sigla com a respectiva cor representa uma associação ou cooperativa e os municípios pertencentes a ela, ou seja, cada entidade tem atuação regional. ACA (Associação dos Cafeicultores de Araguari), com seis municípios; Acanor (Associação dos Cafeicultores do Noroeste), com nove municípios; Acarpa (Associação dos Cafeicultores de Patrocínio), com seis municípios; Amoca (Associação dos Cafeicultores de Monte Carmelo), com nove municípios; Assocafé (Associação dos Cafeicultores de Carmo do Paranaíba), com nove municípios; Assogotardo (Associação dos Cafeicultores de São Gotardo), com cinco municípios; Capal (Cooperativa Agropecuária de Araxá), com sete municípios e Capeca (Cooperativa Agropecuária de Campos Altos), com seis municípios. 
De acordo com informações da Acarpa, a região produtora de café no Cerrado Mineiro tem clima favorável ao desenvolvimento da cultura, com temperatura média de $18{ }^{\circ} \mathrm{C}$ a $22{ }^{\circ} \mathrm{C}$, altitude entre 850 a 1.250 metros e chuvas concentradas nos meses de setembro a abril, com índice pluviométrico em torno dos $1.600 \mathrm{~mm}$ anuais. Esses fatores contribuem sobremaneira para a formação da safra seguinte, propiciando maior qualidade ao produto final ${ }^{9}$, além da reduzida possibilidade de geadas. A topografia é outro fator muito importante, uma vez que a região tem terras pouco acidentadas, permitindo a maior utilização da mecanização durante todo o processo produtivo.

Por todas estas características, a introdução do café foi dinamizada no território. Assim, para a correção do solo e manutenção das plantas, as inovações físico-químicas foram fundamentais ${ }^{10}$. Na etapa de preparo do solo para o plantio, o produtor utiliza a técnica da calagem do terreno, que consiste no corte da terra com a aração e a gradagem, na aplicação de calcário, na adubação orgânica e inorgânica com os nutrientes, tais como o fosfato, o nitrogênio e o potássio. Além desses nutrientes, utilizam-se alguns micronutrientes, como o sulfato de zinco e o ácido bórico, fornecendo, assim, todos os componentes químicos necessários para a planta.

Para o desenvolvimento e a manutenção da planta após o plantio, além da adubação, é preciso controlar as pragas e doenças, empregando herbicidas, fungicidas e outros defensivos agrícolas desenvolvidos por multinacionais que atuam no setor em parcerias com as empresas estatais de pesquisas. Tanto os adubos quanto os defensivos agrícolas são aplicados, em sua maioria, por máquinas modernas. Além do controle de pragas, o herbicida também permite a capina química; o resultado é que o produtor deixa de efetuar a capina mecânica ou braçal, passando uma aplicação do herbicida sobre a vegetação, eliminando-a. A utilização de certos produtos químicos, como os maturadores, permite o desprendimento mais fácil, o amadurecimento mais uniforme e mais rápido dos grãos, agilizando a colheita.

Além de estimular o aumento na produção e na produtividade do café na região, os produtores vêm, aceleradamente, abandonando a prática da colheita manual, passando a recorrer, cada vez mais, à colheita mecânica, para a qual foram necessárias transformações estruturais nas lavouras, como a retirada de arvoredos do meio dos cafeeiros e o alargamento de carreadores. Nesse sentido,

9 Na década de 1990 e início dos anos 2000, a região tem recebido quase todos os dez primeiros prêmios "Brasil de Qualidade de Café Expresso", patrocinados pela empresa italiana Illycafé.

10 Para uma discussão teórica sobre as particularidades das inovações mecânicas, físico-químicas, biológicas e agronômicas na agricultura, consultar Graziano da Silva (1999, p.13-50). 
Território Café do Cerrado: transformações na estrutura produtiva e seus impactos sobre o pessoal ocupado

não somente as máquinas precisam ser adequadas às condições de ambiente, mas também esse ambiente precisa ser adequado às máquinas.

Assim, a colheita mecânica, que consiste no deslocamento de máquinas sobre os cafeeiros ou ao seu lado, exigiu inovações tecnológicas. As primeiras foram as biológicas, que têm avançado acentuadamente, haja vista a manutenção e a atuação de importantes instituições de pesquisa, destacando-se a Epamig ${ }^{11}$ de Patrocínio. No caso do café, os avanços tecnológicos ainda estão distantes de outras culturas, como a da soja ou a do milho, mas foi de fundamental relevância para desenvolver plantas que melhor se adaptassem ao Cerrado, elevassem a produtividade e a qualidade dos grãos, fossem mais resistentes ao ataque de pragas e doenças e apresentassem maturação mais uniforme dos grãos.

Nos últimos anos, as pesquisas continuam concentradas no desenvolvimento de novas variedades mais resistentes e que possam ser mais bem exploradas pelas máquinas. Foram introduzidas, por exemplo, plantas cujos frutos se desprendam mais facilmente das ramas, de porte baixo, galhos distribuídos mais uniformemente ao longo do tronco e maturação mais uniforme, que resulta em períodos definidos de colheita. Além disso, a introdução de variedades precoce, semiprecoce e tardia possibilita melhor distribuição da colheita ao longo do tempo e, como consequência, utilização da maquinaria de maneira mais regular. Esse fato contribui, inclusive, para a redução da depreciação do capital investido.

Outra consequência dessa distribuição da colheita ao longo do ano, além de permitir o uso mais intensivo da máquina, é a menor necessidade de construir grandes terreirões. Reduz-se, assim, a demanda por novos investimentos na ampliação da produção.

Em conjunto, as inovações agronômicas também foram e são fundamentais para a mecanização de todas as atividades presentes na cultura cafeeira; facilitam, também, a aplicação das outras inovações, contribuindo sobremaneira para o aumento da produtividade e a racionalização de operações.

Assim, novas práticas de manejo e organização da cultura foram aplicadas, como o semiadensamento. Com a nova técnica, as ruas de café são mais estreitas, variando de 3 a 4 metros entre ruas e de 0,5 a 1 metro entre plantas, aumentando o número de plantas e a produtividade por hectare. No cultivo tradicional, o número de plantas por hectares raramente ultrapassava os 3.000, enquanto com essa técnica, é de aproximadamente 4.000. Em algumas propriedades, ocorre o "superadensamento", em que as plantas estão a $0,5 \mathrm{~m}$ umas das outras e a apenas $1,8 \mathrm{~m}$ entre as ruas (JESUS, 2003).

Nessa lógica, o plantio de novas lavouras de café na região passou a requerer, cada vez mais, o planejamento, pois tal ação facilita a alocação e locomoção das máquinas e de outros equipamentos. Entretanto, a utilização das máquinas requer outras inovações agronômicas, como o alinhamento dos pés de café, o

11 Empresa de pesquisa agropecuária do estado de Minas Gerais. 
comprimento de suas ruas, a construção de carreadores mais largos, a eliminação de árvores no meio da cultura e, em função da declividade do terreno, o plantio nivelado com curvas de níveis o mais baixo possível.

Outra inovação agronômica, introduzida em função de inovações físico-químicas, está ligada à prática do plantio direto na cafeicultura. Até recentemente, o cultivo do café era realizado com capina mecânica ou manual das ervas daninhas, o que implicava em pelo menos três capinas anuais. Com a nova técnica, mantém-se a vegetação durante quase que o ano inteiro, apenas controlando o seu tamanho com roçadeiras; no momento da preparação para a colheita, é feita uma aplicação de herbicidas (capina química) e, depois, a mecânica, para o preparo da terra para a colheita. Assim, ocorre redução de custos e manutenção de massa verde, o que contribui para preservar a umidade do solo.

A irrigação no Cerrado tem sido outra importante inovação. Sua utilização no momento da florada tem possibilitado uma uniformização do amadurecimento dos frutos, favorecendo o uso de máquinas na colheita, além de conferir melhor qualidade ao produto.

Assim, as inovações mecânicas, facilitadas pelo fator geográfico, tem sido intensificadas na cafeicultura do Cerrado Mineiro e possibilitado maior eficiência econômica. Seu solo relativamente plano permite o deslocamento dos mais variados instrumentos de trabalho, que, acoplados aos tratores, realizam o preparo do solo, o plantio e a aplicação de tratos culturais, aumentado a velocidade e a qualidade das atividades executadas, reduzindo, assim, o dispêndio com mão de obra.

Entre as inovações mecânicas recentes introduzidas na cafeicultura da região, destacam-se a mecanização da colheita, iniciada na década de 1970, mas, foi somente na década de 1990 que se intensificou. Foi nessa fase que a utilização das máquinas apresentou um impacto mais significativo, pois a colheita na atividade cafeeira demanda um grande contingente de mão de obra temporária; em média, essa fase chega a ocupar $40 \%$ da força de trabalho necessária na atividade, segundo Cruz Neto e Matiello (1981).

No processo de colheita, após todo o preparo inicial de eliminação das pragas e da arruação (preparo do solo), o produtor poderia contratar o trabalhador braçal para efetuar a colheita. No entanto, ele utiliza cada vez mais a máquina em movimento no seu cafezal, retirando o maior número possível de grãos dos pés de café e recolhendo-os diretamente em uma carreta, que se desloca junto com a máquina, ou em sacos, denominados de big bag ${ }^{12}$, e logo são recolhidos por tratores e outros equipamentos. O restante dos grãos que ficam nos pés de

12 Big bag são grandes sacos de material resistente, utilizados no caso da agricultura, para facilitar no transporte em geral de grãos, adubos, batatas etc. Tais sacos chegam a comportar uma tonelada de carga. 
Território Café do Cerrado: transformações na estrutura produtiva e seus impactos sobre o pessoal ocupado

café, que podem variar de $2 \%$ a $20 \%$, dependendo da maturidade dos grãos ou do tipo e regulagem das colheitadeiras, é derriçado logo em seguida por trabalhadores braçais.

Em um terceiro momento, ocorre o levantamento dos grãos que estavam no chão junto ao restante que foi derriçado. Esse processo pode ocorrer de duas formas: a primeira conta com trabalhadores braçais, que arrastam os grãos que ficam debaixo dos pés de café e, com a utilização de peneiras, fazem a separação dos grãos das impurezas. Na segunda forma, que se desenvolveu de forma acentuada após os anos 2000, conta, num primeiro momento, com máquinas ou trabalhadores que arrastam os grãos de baixo dos pés de café e, em seguida, utilizam outra máquina que se desloca sobre o café puxado e faz o levantamento, ou seja, a separação dos grãos das impurezas e ensacamento do café.

Como pode-se notar, essas inovações na cultura cafeeira transformaram toda a estrutura agrícola, pois reduziram a demanda por mão de obra temporária e desqualificada, trabalhadores braçais em sua maioria, e aumentaram a demanda por trabalhadores especializados, como tratoristas, mecânicos, motoristas, operadores de máquinas e beneficiamento, trabalhadores de irrigação etc ${ }^{13}$.

Assim, a cultura do café, que se destacava por ser uma atividade que absorvia um grande contingente de mão de obra rural nos diversos municípios do Cerrado Mineiro, principalmente na fase da colheita, vem perdendo este posto. Além da fase de colheita, na fase de produção, demanda-se mão de obra no período de plantio e replantio das áreas em expansão e na manutenção da cultura, como na desbrota, na capina e na aplicação de tratos culturais ${ }^{14}$. Todavia, em muitas destas fases, é o trator que, acoplado a determinados implementos realiza as atividades, requerendo, assim, um pequeno contingente de trabalhadores, se comparado com o período de colheita.

Segundo os dados obtidos nas entrevistas realizadas com técnicos do setor (agrônomos das associações de produtores, de empresas de pesquisa e assistência técnica oficial, das próprias empresas prestadoras de serviços e das revendas), estima-se que, em 1990, a quantidade de colhedeiras mecânicas no Cerrado Mineiro era de cerca de 80. No início dos anos 2000, o número de colheitadeiras na região se aproximava das 300 unidades e, no fim da década, esse número subiu significativamente, ultrapassando, de acordo com os dados obtidos nas entrevistas, 420 unidades.

13 A demanda e a intensidade do trabalho se diferenciam de acordo com o tamanho da propriedade, a tecnologia utilizada e a quantidade de café nos pés.

14 É importante observar que, entre estas atividades, apenas a desbrota e o replantio não são passíveis de mecanização. Recentemente foi desenvolvido um implemento que pode realizar o plantio mecânico contando com apenas um operador e dois ajudantes, substituindo um grande número de trabalhadores. 
De acordo com Jesus (2003) e Ortega, Garlipp e Jesus (2003) a colheitadeira de café colhe, em média, 60 sacos de café por hora, em um período entre 18 e 22 horas por dia, substituindo, de tal modo, mais de 100 trabalhadores em único dia de serviço. Assim, a sua utilização poupa entre $30 \%$ e $40 \%$ dos custos de colheita em relação ao uso da mão de obra volante, de acordo com técnicos e produtores entrevistados.

O percentual exato de redução de custos é variável e depende de uma série de características na operação da colheita. Para lavouras com produção acima da média mineira, entre 30 e 35 sacos por hectare, Silva et al. (1997) e Silva e Salvador (1998), observaram redução de custos no sistema mecanizado de aproximadamente $40 \%$ em relação ao manual.

Essas colheitadeiras estão concentradas nas empresas prestadoras de serviços, que surgem a cada ano, e na mão de grandes produtores, uma vez que o valor comercial de cada máquina é bem elevado, e o tempo de uso de uma máquina para a colheita de café é bem reduzido, ocorrendo entre maio e agosto de cada ano, o que dificulta a sua depreciação ao longo do tempo. No Seminário do Café do Cerrado, realizado no município de Patrocínio (MG) em 2009, pôde-se constatar que as máquinas colheitadeiras têm sido comercializadas entre R\$ 200 mil e R\$ 500 mil, um valor bem elevado para depreciação em apenas quatro meses. Desse modo, é necessário utilizar as máquinas em grandes áreas de lavouras a cada ano, para assim, depreciá-las em um menor espaço de tempo.

Nessa situação, a aquisição somente é viável para os grandes produtores ${ }^{15}$ e para as empresas prestadoras de serviços, sendo que, para os pequenos e médios produtores, a terceirização é a opção mais indicada. A atividade da terceirização da colheita possibilita-lhes efetuar o pagamento de uma tarifa de locação por máquina, que entra em sua propriedade e efetua a colheita da área contratada. Essa tarifa varia de acordo com o modelo de máquina que executa o serviço, entre R \$130,00 e R\$ 160,00 por hora, segundo valores apurados juntos aos cafeicultores entrevistados.

Normalmente, a prestação de serviço também é estendida a grandes propriedades que não querem arcar com os custos de manutenção e de depreciação do maquinário. Para empresas terceirizadoras, isso torna viável adquirir seu maquinário e alugá-lo, pois, com a prestação de serviço a várias propriedades, ela maximiza a utilização de suas máquinas.

Esse novo ramo de atividade, o aluguel de colheitadeiras, é um segmento composto por empresários que não são necessariamente cafeicultores, tratando-se de empresas especializadas na terceirização das máquinas na época da

15 Na atividade cafeeira, produtores são enquadrados como minifundistas - até 10 hectares; pequenos cafeicultores - de 10 a 20 hectares; médios cafeicultores - de 20 a 50 hectares; e grandes cafeicultores - acima de 50 hectares. Entretanto, certos modelos de colheitadeiras só são viáveis para as propriedades com mais de 100 hectares. 
Território Café do Cerrado: transformações na estrutura produtiva e seus impactos sobre o pessoal ocupado

colheita (GARLIPP, 1999). Em alguns casos, são os produtores quem adquirem as máquinas de colheita, executam o seu serviço e, nos intervalos em que o equipamento encontra-se desocupado, prestam serviços a seus vizinhos.

Nas pesquisas de campo nos municípios-polo da cafeicultura da região, foram encontradas várias empresas prestadoras de serviços, algumas com mais de 20 anos de atividade e mais de 20 colheitadeiras para serem alugadas, o que evidencia o avanço da atividade de prestação de serviços mecanizados.

\section{Inovações tecnológicas na cafeicultura do Cerrado Mineiro e seus impactos sobre o processo produtivo}

Os dados do censo agropecuário de 2006 demonstram a importância e as particularidades da cafeicultura no Cerrado Mineiro. Na Tabela 1, pode-se verificar, por exemplo, a produção dos cafés arábica e café canephora, denominado conilon, alcançada por aquela região. A produção brasileira de café está concentrada na primeira variedade, com $80 \%$ da produção total. O percentual dessa variedade, no Cerrado Mineiro, entretanto, está presente em 96,2\% dos estabelecimentos no ano de referência da pesquisa censitária, 2006. Por ser uma variedade de café de maior produtividade e de melhor qualidade da bebida, no Cerrado Mineiro, cuja produção é dirigida aos mercados nacionais e internacionais mais exigentes, é que ocorre aquela elevada concentração da variedade arábica.

Já a variedade canephora, denominada conilon, tem pequena participação do estado de Minas Gerais em relação ao Brasil, de aproximadamente 10\%. No Cerrado Mineiro, estão apenas 193 estabelecimentos com tal variedade, produzindo perto de $16 \%$ da produção do estado.

Os dados censitários de 2006 revelam a importância da cafeicultura em Minas Gerais, expressa na participação de 52,24\% dos estabelecimentos de café arábica do Brasil (104.939), e por 64,98\% da produção do país (Tabela 1), dado que revela uma produtividade média superior à brasileira. Enquanto isso, no território do Cerrado Mineiro, encontram-se 4.879 estabelecimentos, equivalentes a apenas $4,65 \%$ dos estabelecimentos de Minas Gerais, mas que respondem por 20,14\% do café arábica no estado, o que demonstra a elevada produtividade da região em relação ao estado. 


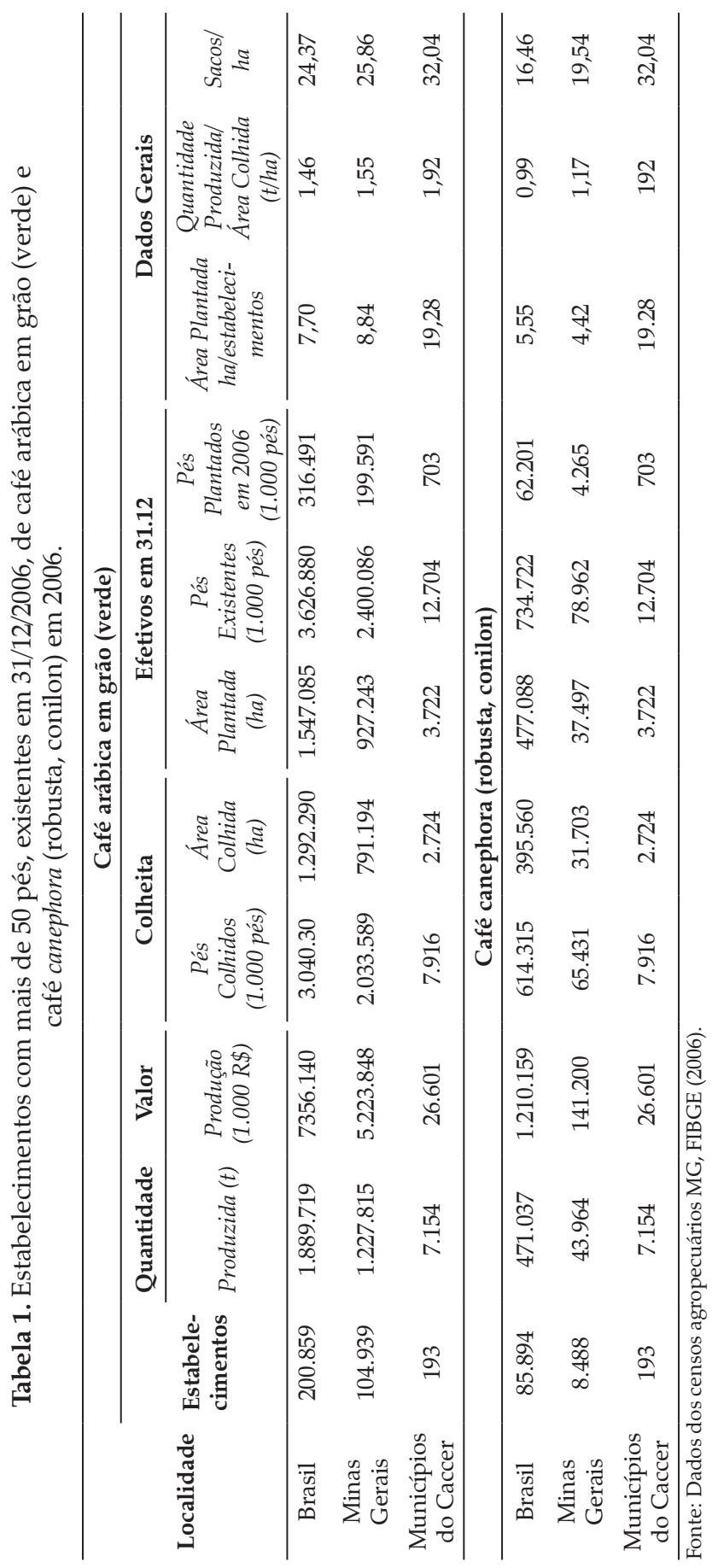


Território Café do Cerrado: transformações na estrutura produtiva e seus impactos sobre o pessoal ocupado

Essa participação reduzida no número de estabelecimentos produtores de café no estado de Minas Gerais (4,65\%), ante uma participação de 20,14\% do volume de produção do café arábica, ocorre em função da elevada produtividade média alcançada, 33,77 sacas por hectare, enquanto a mineira foi de 25,88 . Interessante observar, ainda, quando se compara a realidade da cafeicultura do Cerrado Mineiro com a de todo o estado, é que o tamanho médio dos estabelecimentos no Cerrado Mineiro é de aproximadamente 30 hectares, enquanto no estado não chega a nove hectares. Esse tamanho médio superior dos estabelecimentos do Cerrado Mineiro influencia de forma direta na aplicação das inovações tecnológicas, particularmente, as agronômicas e as mecânicas, que propiciam uma produtividade mais elevada que a média mineira.

Como resultado, além dessa participação superior no volume de produção do Cerrado Mineiro, quando comparado com o número de estabelecimentos, essa produtividade média é alcançada com um produto de qualidade média superior ao de outras regiões que, associado às conquistas obtidas na consolidação da construção de uma marca reconhecida, dão uma rentabilidade superior à média estadual. Assim, aquela região detém 22,38\% do valor gerado na produção de café no estado.

Ainda com relação aos dados da Tabela 1, pode-se verificar que os produtores de café continuam investindo na produção, haja visto o número de pés plantados em 2006. No Cerrado Mineiro, houve um incremento de aproximadamente $10 \%$ de pés de café em relação aos 472 milhões do ano anterior. Essa ampliação foi obtida, em parte, com a ampliação da área plantada, mas também com a renovação de lavouras já esgotadas, utilizando a técnica do adensamento.

Os dados da Tabela 2 ajudam a compreender melhor a estrutura fundiária nos municípios do Caccer, que apresentam uma dinâmica diferenciada em relação ao estado e ao país. Fica evidente, a partir de seus dados, que o tamanho médio dos estabelecimentos agropecuários nesses municípios supera em área o tamanho médio encontrado em Minas Gerais e no Brasil. Enquanto para o total de estabelecimentos agropecuários a média do país é de 63,75 ha, no território do café do Cerrado é de 144,13 ha. Ao dividir esses estabelecimentos entre agricultura familiar e não familiar, no estado mineiro, tem-se 20,22 ha e 208,42 ha, respectivamente, enquanto nos municípios do Caccer estas áreas saltam para 38,91 ha na agricultura familiar e 395,17 ha na agricultura patronal. 
Tabela 2. Área total, número e área média dos estabelecimentos agropecuários por tipo de utilização.

\begin{tabular}{|c|c|c|c|c|c|}
\hline & \multicolumn{2}{|c|}{ Discriminação } & \multirow{2}{*}{$\begin{array}{c}\text { Brasil } \\
329.941 .393\end{array}$} & \multirow{2}{*}{$\begin{array}{c}\text { Minas Gerais } \\
32.647 .547\end{array}$} & \multirow{2}{*}{$\frac{\text { Mun. Caccer }}{7.240 .716}$} \\
\hline \multirow{9}{*}{ Total } & \multirow{3}{*}{$\begin{array}{c}\text { Área dos } \\
\text { Estabelecimentos } \\
\text { Pecuários }\end{array}$} & Total & & & \\
\hline & & Não Familiar & 249.690 .940 & 23.801 .664 & 5.863 .137 \\
\hline & & $\begin{array}{l}\text { Agricultura } \\
\text { Familiar }\end{array}$ & 80.250 .453 & 8.845 .883 & 1.377 .576 \\
\hline & \multirow{3}{*}{$\begin{array}{l}\text { Número de } \\
\text { Estabelecimentos } \\
\text { Agropecuários } \\
\text { (Un) }\end{array}$} & Total & 5.175 .489 & 551.617 & 50.238 \\
\hline & & Não Familiar & 807.587 & 114.202 & 14.837 \\
\hline & & $\begin{array}{l}\text { Agricultura } \\
\text { Familiar }\end{array}$ & 4.367 .902 & 437.415 & 35.401 \\
\hline & \multirow{3}{*}{$\begin{array}{l}\text { Área Média por } \\
\text { (ha) }\end{array}$} & Total & 63,75 & 59,19 & 144,13 \\
\hline & & Não Familiar & 309,18 & 208,42 & 395,17 \\
\hline & & $\begin{array}{l}\text { Agricultura } \\
\text { Familiar }\end{array}$ & 18,37 & 20,22 & 38,91 \\
\hline \multirow{9}{*}{$\begin{array}{c}\text { Lavouras } \\
\text { Permanentes }\end{array}$} & \multirow{3}{*}{$\begin{array}{c}\text { Área dos } \\
\text { Estabelecimentos } \\
\text { Pecuários }\end{array}$} & Total & 11.612 .227 & 1.713 .511 & 241.541 \\
\hline & & Não Familiar & 7.321 .986 & 1.134 .056 & 205.253 \\
\hline & & $\begin{array}{l}\text { Agricultura } \\
\text { Familiar }\end{array}$ & 4.290 .241 & 579.456 & 36.252 \\
\hline & \multirow{3}{*}{$\begin{array}{l}\text { Número de } \\
\text { Estabelecimentos } \\
\text { Agropecuários } \\
\text { (Un) }\end{array}$} & Total & 1.480 .243 & 239.949 & 11.831 \\
\hline & & Não Familiar & 246.629 & 49.255 & 3.895 \\
\hline & & $\begin{array}{l}\text { Agricultura } \\
\text { Familiar }\end{array}$ & 1.233 .614 & 190.964 & 7.936 \\
\hline & \multirow{3}{*}{$\begin{array}{l}\text { Área Média por } \\
\text { (ha) }\end{array}$} & Total & 7,84 & 7,14 & 20,42 \\
\hline & & Não Familiar & 29,69 & 23,02 & 52,70 \\
\hline & & $\begin{array}{l}\text { Agricultura } \\
\text { Familiar }\end{array}$ & 3,48 & 3,04 & 4,57 \\
\hline
\end{tabular}

Fonte: Dados dos censos Agropecuários MG, FIBGE (2006).

Área média: resultado da divisão da área dos estabelecimentos pelo número de estabelecimentos.

A mesma dinâmica é encontrada nas lavouras permanentes; entretanto, em menor dimensão, pelas características de manutenção desse tipo de lavoura, como é o caso do café. Nesse caso, o tamanho médio do estabelecimento agropecuário com produção de lavouras permanentes no território do café do Cerrado é muito superior às médias mineira e brasileira, principalmente para os estabelecimentos não familiares. Nesse tipo de estabelecimento, a área alcança média de 52,70 ha, enquanto a média mineira é de 23,02 ha e, do Brasil, de 29,69 ha. Já agricultura familiar registrou apenas 4,57 ha nos municípios do Caccer, 3,04 ha no estado e 3,48 ha no Brasil. Tais fatos demonstram que a atividade cafeeira no Cerrado Mineiro tem caráter excludente, em função do avanço técnico, do capital aplicado, entre outras características apresentadas. 
Território Café do Cerrado: transformações na estrutura produtiva e seus impactos sobre o pessoal ocupado

A Tabela 3 reforça o argumento de que a participação da agricultura familiar em lavouras permanentes nos municípios que compõem o Caccer é relativamente pequena. Em Minas Gerais, o percentual de agricultores familiares participando da produção de lavouras permanentes chega a 33,82\%, média próxima à brasileira. Entretanto, a participação destes agricultores no território do café do Cerrado Mineiro representa apenas 15,01\%. Logo, o percentual do número de estabelecimentos nesse tipo de lavouras é menor. Quando se verificam os dados de área total, que abarca outras atividades, como as lavouras permanentes e a pecuária, estes percentuais aumentam. Assim, o percentual da área total da agricultura familiar supera os $19 \%$, um pouco inferior à média nacional.

Tabela 3. Participação percentual da agricultura familiar.

\begin{tabular}{ccccc}
\hline & \multicolumn{2}{c}{ Área Total } & \multicolumn{2}{c}{ Lavouras Permanentes } \\
\cline { 2 - 5 } & $\begin{array}{c}\text { \% de área total da } \\
\text { agricultura familiar número de }\end{array}$ & $\begin{array}{c}\text { \% de área total da } \\
\text { estabelecimentos da } \\
\text { agricultura familiar }\end{array}$ & $\begin{array}{c}\text { \% do número de } \\
\text { estabelecimentos da } \\
\text { agricultura familiar } \\
\text { agricultura familiar }\end{array}$ \\
\hline Brasil & 24,32 & 84,40 & 36,95 & 83,34 \\
Minas Gerais & 27,10 & 79,30 & 33,82 & 79,47 \\
Mun. Caccer & 19,03 & 70,47 & 15,01 & 67,08 \\
\hline
\end{tabular}

Fonte: Dados dos censos agropecuários MG, FIBGE (2006).

Analisando-se melhor a atividade cafeeira no Cerrado Mineiro, fica ainda mais evidente seu crescimento quando são tomados como base os dados dos censos agropecuários desde 1970, com a implantação da cafeicultura na região, até o censo de 2006. Observando-se os dados relativos às lavouras permanentes dos 55 municípios que constituem o Caccer, e conforme o que é denominado de território do café do Cerrado, constata-se que houve uma ampliação dessas lavouras em quase $700 \%$ no período de 1970 a 2006. De acordo com os dados dos censos agropecuários, essa área passou de 35.676 ha, em 1970, para 241.538 ha em 2006 (Tabela 4). Como na região a principal cultura permanente é o café, os dados corroboram o crescimento da cultura.

Em 2006, dos 241.538 ha, 147.423 ha estavam ocupados com café, o que equivale a $61 \%$ da área total. Entretanto, o crescimento da lavoura cafeeira se deu de forma mais acentuada, pois, em 1970, a produção de café em escala comercial era inexpressiva na região. Conforme os dados da Tabela 4, o incremento de lavouras permanentes nessa região ocorre bem acima da média mineira, o que demonstra a importância que a cultura cafeeira dessa região assume no estado de Minas Gerais ao longo dos últimos 30 anos. 
Tabela 4. Lavouras permanentes no estado de Minas Gerais e nos municípios do Caccer, em hectares.

\begin{tabular}{ccccccc}
\hline Ano & 1970 & 1975 & 1980 & 1985 & $1995 / 96$ & 2006 \\
\hline $\begin{array}{c}\text { Lavouras } \\
\text { permanentes - MG }\end{array}$ & 548.505 & 655.363 & 1.135 .748 & 1.288 .913 & 1.188 .053 & 1.713 .511 \\
\hline $\begin{array}{c}\text { Lavouras permanentes } \\
\text { nos municípios } \\
\text { do Caccer }\end{array}$ & 35.676 & 52.639 & 118.044 & 149.730 & 161.086 & 241.538 \\
\hline $\begin{array}{c}\text { Lavouras temporárias } \\
\text { nos municípios } \\
\text { do Caccer }\end{array}$ & 392.105 & 604.064 & 671.962 & 943.961 & 954.907 & 1.304 .953 \\
\hline
\end{tabular}

Fonte: Dados dos censos agropecuários MG, FIBGE (1970, 1975, 1980, 1985, 1995/96 e 2006).

Os dados dos censos agropecuários confirmam, ainda, o avanço do uso da mecanização no Cerrado Mineiro, com a intensificação do emprego de modernos instrumentos de trabalho. Para o total dos municípios produtores do Caccer, o salto foi de 1.691 tratores em 1970, para 23.400 em 2006. Crescimento próximo ocorreu no estado de Minas gerais (Figura 2). Entretanto, verifica-se uma inflexão no ritmo de aumento de tratores entre 1995/96 e 2006, uma queda acompanhada de uma modificação na potência dos novos tratores adquiridos. Assim, por meio da Figura 3, pode-se perceber o crescimento na utilização dos tratores acima de $100 \mathrm{CV}^{16}$ de potência, tanto no estado de Minas Gerais quanto nos municípios do Caccer, o que indica o avanço no estoque de tratores com maior capacidade de tração de equipamentos.

16 CV é um termo que significa cavalo e está relacionado com a medida de força (potência) de tração do trator utilizada no dia-a-dia dos profissionais que lidam com a agricultura. 
788 - Território Café do Cerrado: transformações na estrutura produtiva e seus impactos sobre o pessoal ocupado

Figura 2. Total de tratores em Minas Gerais e nos municípios do Caccer.

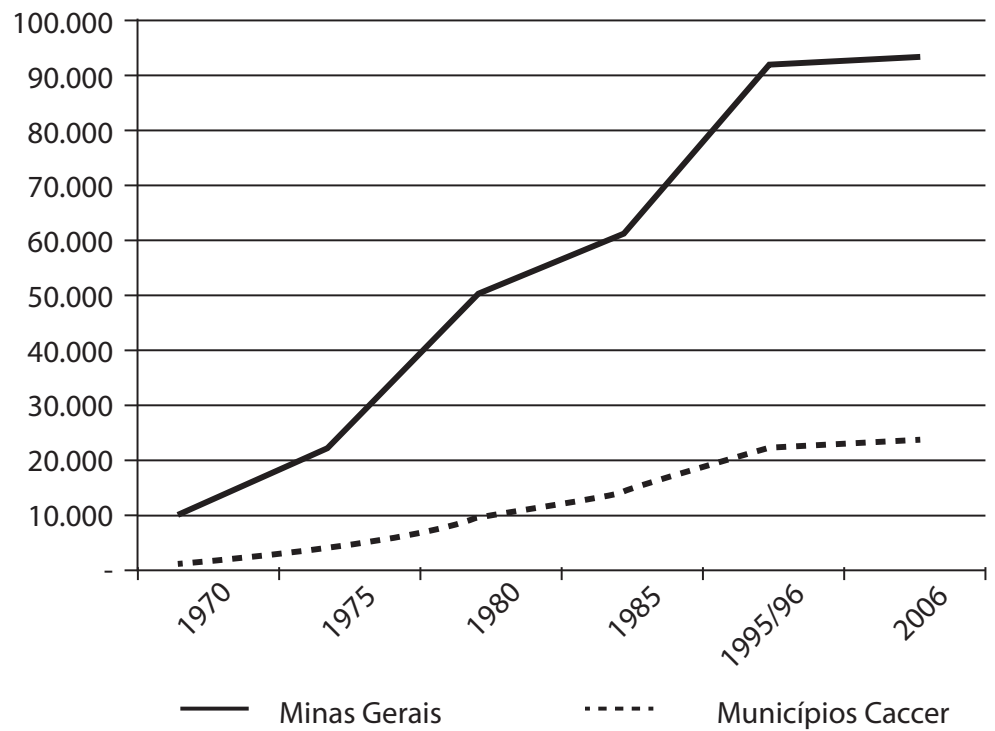

Fonte: Dados dos censos agropecuários MG, FIBGE (1970, 1975, 1980, 1985, 1995/96 e 2006).

Figura 3. Tratores por potência em Minas Gerais e nos municípios do Caccer.

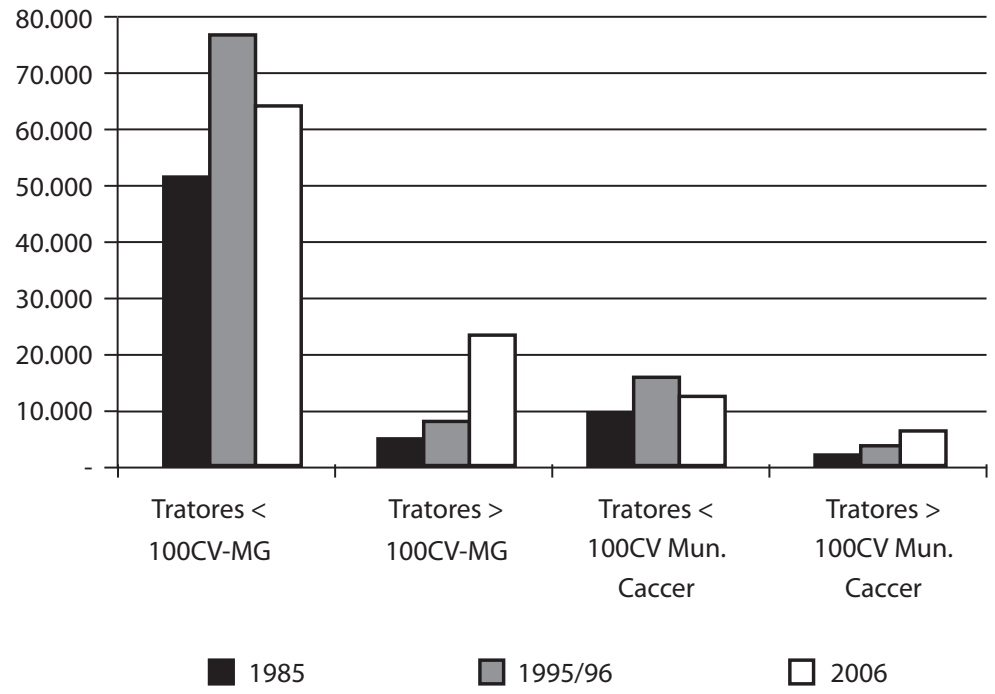

Fonte: Dados dos censos agropecuários MG, FIBGE (1985, 1995/96 e 2006). 
Ao levar em consideração o número de tratores e a área de lavouras permanentes e temporárias nos municípios do Caccer, entre 1970 e 2006, verificam-se que a razão trator por hectare reduziu 74\%, passando de 253 hectares por trator para 66 hectares.

É bom ressaltar, no entanto, que o comportamento quanto ao uso de tratores entre os 55 municípios do Caccer não é homogêneo. Nos municípios que concentram a atividade cafeeira, pode-se notar avanço ainda maior no processo de mecanização. Ao separar os principais municípios produtores de café no território, aqueles com mais de 5.000 hectares de café plantados, o que totaliza dez municípios, verifica-se um percentual maior de tratores abaixo de $100 \mathrm{CV}$ de força. Enquanto na média do território, 67\% dos tratores são inferiores a essa potência, naqueles dez municípios, esse percentual salta para $77 \%$; em Patrocínio, o principal município produtor de café do território, o percentual chega a $80 \%$.

Sendo assim, fica evidenciada a elevada mecanização da atividade cafeeira, que demanda tratores com potência entre $50 \mathrm{CV}$ e $80 \mathrm{CV}$ de forma intensiva em relação a outras atividades agrícolas. Tomando-se como parâmetro o município de Patrocínio, por concentrar 16,30\% da área plantada de café no território, com 23.037 hectares, a utilização de trator por hectare, mantendo-se a relação lavouras permanentes e temporárias, chega a 35,65 hectares por trator. Média próxima é encontrada nos principais produtores de café. Em Patrocínio, a frota de tratores passou de apenas 21 em 1970 para 1.567 em 2006. Esse comportamento foi encontrado em outros municípios produtores de café.

Portanto, esses dados confirmam a hipótese de que, ainda que dados para mecanização não permitam identificar exclusivamente aquela dirigida à cafeicultura, a intensificação do uso de tratores de médio porte leva a acreditar que são equipamentos dirigidos à cafeicultura.

Com as transformações apontadas no número e na potência dos tratores, os instrumentos de trabalho que são acoplados a eles também apresentaram significativas modificações. O número de arados de tração animal, no estado mineiro, apresentou crescimento entre 1970 e 1985; depois, apresentou acentuada queda no censo agropecuário de 1995/96. Enquanto isso, os municípios do Cerrado Mineiro, que tinham um estoque de arados de tração animal na casa das 20.000 unidades até o censo agropecuário de 1985, tiveram seu estoque reduzido à metade dez anos depois (Figura 4). O censo de 2006 não apurou informações desses arados, mas a tendência é de queda acentuada, pois a prática da utilização de animais vem sendo abandonada.

Já os arados de tração mecânica registraram crescimento contínuo ao longo do período em Minas Gerais. Em 1970, havia apenas 10.206 arados desse tipo, enquanto que em 2006, esse número havia saltado para 67.450 (Figura 4). Nos municípios do Caccer, porém, o comportamento foi distinto, visto que, entre 1970 e 1995/96, o número de arados cresceu acentuadamente, passando de 1.779 
Território Café do Cerrado: transformações na estrutura produtiva e seus impactos sobre o pessoal ocupado

para 15.496. Mas, do censo de 1995/96 para o de 2006 houve queda significativa, reduzindo para 9.858 arados. Essa queda é explicada, em parte, pela prática da manutenção de massa verde no meio das ruas de café, o que reduziu drasticamente a prática da aragem e gradagem nos cafeeiros, conforme explicado anteriormente, ao ter sido ressaltada a inovação agronômica introduzida no controle de ervas daninhas, o que reduziu as capinas. Há que se destacar, ainda, o aumento médio da potência dos tratores, que introduziu equipamentos de maior porte, principalmente para as lavouras temporárias.

Figura 4. Total de arados de tração animal e mecânica em Minas Gerais e nos municípios do Caccer.

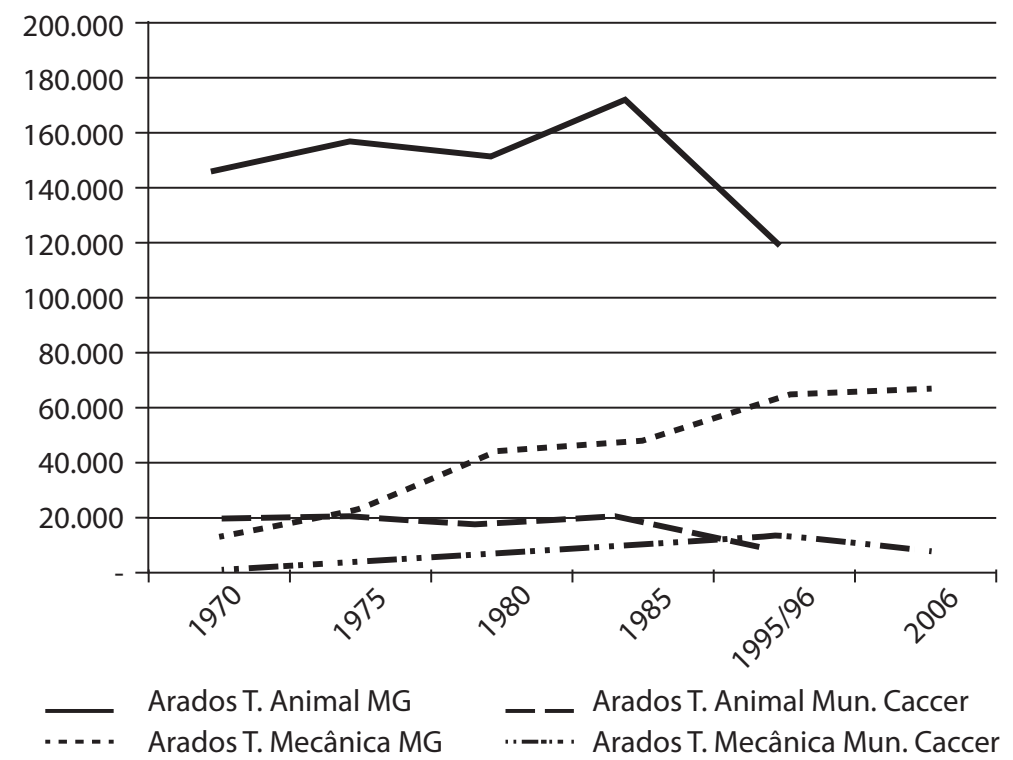

Fonte: Dados dos censos agropecuários MG, FIBGE (1970, 1975, 1980, 1985, 1995/96 e 2006).

O comportamento das máquinas de plantio (Figura 5) manteve-se praticamente estável entre 1980 e 2006, tanto no estado quanto nos municípios do território do café. Nesses municípios, o número de máquinas para plantio era de 6.410 em 1980; chegou a 8.115 em 1995/96 e, depois, apresentou redução no censo de 2006, para 7.083 máquinas. Mesmo com números estáveis, a mecanização do plantio das culturas temporárias avançou muito no período, pois houve o abandono de máquinas de tração animal e a ampliação das máquinas de tração mecânica. Ao mesmo tempo, a capacidade de trabalho de tais máquinas foi ampliada significativamente, acompanhando o aumento médio da potência dos novos tratores. Como exemplo: plantadeiras que, em 1980 trabalhavam entre dois e três metros em linha de plantio, hoje trabalham entre cinco a seis metros. 
O crescimento de máquinas para plantio só não foi maior porque, na atividade de plantio do café, mesmo com o desenvolvimento de uma máquina específica, a prática manual continua como o principal meio utilizado.

Desse modo, o uso do trator com os diversos equipamentos acoplados tem substituído lentamente muitos trabalhadores em atividades tradicionais do campo, seja no preparo do solo, no plantio ou nos tratos culturais. Porém, o impacto mais significativo sobre o pessoal ocupado está na fase da colheita, pois essa atividade demanda muita mão de obra braçal, principalmente.

Figura 5. Número de máquinas para plantio e colheita em Minas Gerais e nos municípios do Caccer.

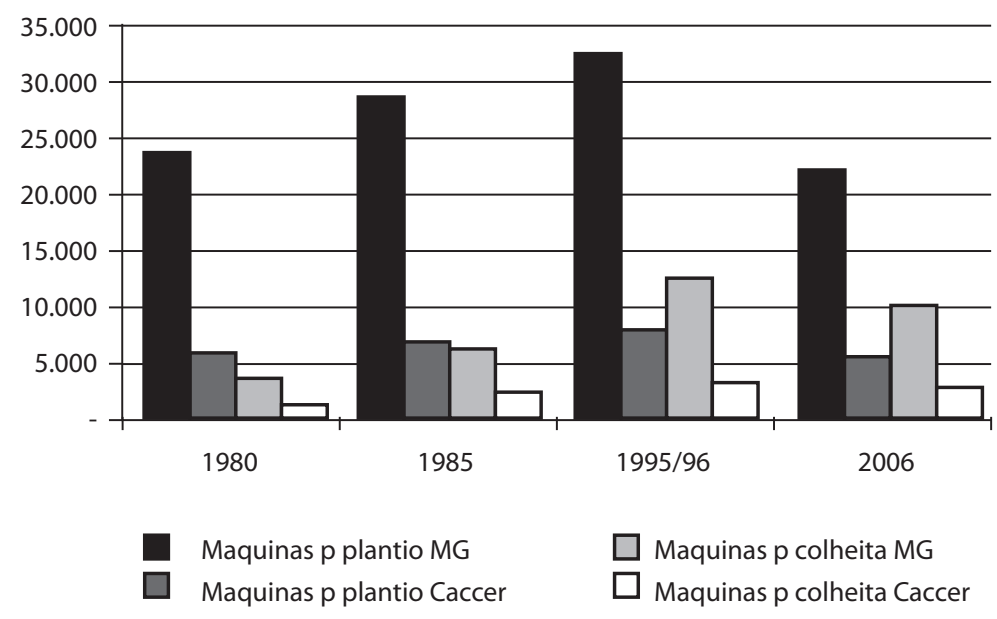

Fonte: Dados dos censos agropecuários MG, FIBGE (1980, 1985, 1995/96 e 2006).

O número de máquinas para colheita nos municípios do Caccer aumentou 170\% entre 1980 e 1995/96, passando de 1.246 máquinas em 1980, passando por 2.099 em 1985, e chegando a 3.369 em 1995/96. Porém, no censo agropecuário de 2006, houve queda de $11 \%$, passando para 2.986 máquinas, indicando que a colheita mecanizada deixou de crescer, uma vez que a área plantada na região continuou expandindo (Tabela 4). Na Figura 5 fica evidente que, em Minas Gerais, ocorreu situação semelhante com o estoque de máquinas para colheita.

Entretanto, não se pode considerar essa possibilidade de redução da mecanização sem antes compreender outros fatores que justificam tal queda no estoque de máquinas na ampliação da mecanização da fase de colheita. Assim como ocorreu com as máquinas para plantio, entre os anos 80 e os 2000, a capacidade de cada colheitadeira aumentou significativamente. Assim, a substituição de uma colheitadeira depreciada por outra moderna amplia a sua capacidade de trabalho. Ao mesmo tempo, parte dessas colheitadeiras, quando 
Território Café do Cerrado: transformações na estrutura produtiva e seus impactos sobre o pessoal ocupado

substituída, é transferida para outras regiões de fronteira agrícola, sendo utilizadas, principalmente, em culturas temporárias.

Como já havia sido ressaltado, uma transformação relativamente recente na região é o surgimento de diversas empresas prestadoras de serviços, especialmente as de colheita do café, o que leva ao deslocamento de parte das máquinas para a colheita, bem como de outros equipamentos de prestação de serviços, para as sedes das empresas nas cidades da região. Assim, essa fatia de máquinas e equipamentos não é contabilizada como informações dos estabelecimentos rurais, reduzindo o efetivo real presente nas atividades agrícolas.

O processo de mecanização da colheita de café evoluiu de maneira distinta quando comparado com outras culturas, particularmente as temporárias, como soja ou milho, que adotam a mecanização em todas as fases do processo produtivo, desde os anos 70. Como consequência, um crescimento ou troca no quadro de colheitadeiras dessas culturas acaba gerando pouco desemprego na região. Ao contrário, no caso da cafeicultura, a adoção de máquinas na colheita leva a uma significativa redução no quadro de trabalhadores temporários da região, pois essa é a principal cultura em geração de emprego durante a colheita na região.

Pelo fato de o censo agropecuário registrar o número total de máquinas para colheita nos municípios, sem separação do destino de cada máquina, se café, soja, ou milho, procurou-se analisar de forma mais detalhada o número de máquinas por município. Trata-se de um comportamento bastante distinto de município para município. Naqueles em que se concentram lavouras temporárias, como Unaí, Paracatu, Ibiá, entre outros, houve queda superior a $20 \%$ no quadro de máquinas para colheita entre 1995/96 e 2006. Em Paracatu, existiam 74 máquinas para colheita em 1980, chegando a 259 em 1995/96 e, em 2006, a cidade tinha apenas 170, o que não significa redução da mecanização, devido ao aumento de eficiência das novas colheitadeiras.

Por outro lado, quando os principais municípios produtores de café são separados, embora haja lavouras temporárias, mas em menor proporção, encontram-se três situações distintas: acréscimo no número de máquinas, manutenção, ou ligeira queda. Municípios como Carmo do Paranaíba, Coromandel, Monte Carmelo, Rio Paranaíba e Serra do Salitre apresentam aumento. Em Monte Carmelo, o número de máquinas para colheita saltou de 46 em 1995/96 para 78 em 2006. Já Patrocínio teve a frota de máquinas para colheita mais que triplicada, passando de 48 em 1980, para 54 em 1985 e 176 em 1995/96. Isso significou um crescimento médio de $12,54 \%$ ao ano no período, patamar que se manteve até o censo agropecuário de 2006, que registrou 172 máquinas colheitadeiras. Esse resultado, entretanto, não significou estabilização da área colhida mecanicamente, mas sim, que o tamanho médio das máquinas aumentou. 
Como consequência das mudanças apontadas na região, como o aumento na área de produção, ampliação do quadro de tratores, arados e grades bem como outros equipamentos agrícolas, como pulverizadores, arruadores, máquinas para plantio e, especialmente, para a colheita, o número de pessoas ocupadas no meio rural apresentou fortes transformações ao longo dos 36 anos analisados.

Conforme a Tabela 5, referente ao pessoal ocupado em Minas Gerais e nos municípios do Caccer $^{17}$, existem comportamentos distintos de modernização da produção agrícola e seus impactos. Em um primeiro momento, entre os censos de 1970 e 1985, percebe-se uma ampliação no número total de pessoas ocupadas $^{18}$ nos estabelecimentos agropecuários, tanto no estado quanto no território do café. No estado, o crescimento no período foi de $34,36 \%$, enquanto nos municípios do Caccer, o aumento foi de $51,32 \%$, fato que se deve à ampliação de área produtiva na região, principalmente, o café.

Entretanto, à medida que se intensificou a introdução de máquinas nas diversas atividades agrícolas, o número total de pessoas ocupadas passou a cair. A partir do censo agropecuário de 1995/96, o número de pessoas ocupadas decresce. Essa queda foi de 24,81\% em Minas Gerais, e de 27,95\% nos municípios do Caccer. Nesse sentido, a expectativa era de que os dados do censo agropecuário de 2006 apresentassem números ainda piores em termos de pessoal ocupado, particularmente em função do avanço da mecanização. Em artigo anterior, Ortega e Jesus (2003), tomando como referência o censo de 1995/96, chegam a projetar uma taxa de redução superior a $2 \%$ ao ano para os municípios do Caccer.

17 O número total de pessoas ocupadas nos Censos Agropecuários envolve as pessoas com laço de parentesco e sem laço de parentesco que exerceram alguma atividade dentro do estabelecimento agropecuário.

18 Apesar de agregar os trabalhadores de todas as atividades rurais, foram utilizados os dados censitários como proxy para se observar o comportamento do emprego na cafeicultura. Essa atividade é uma das que mais ocupam força de trabalho nos municípios do Caccer e que mais apresentou oscilações nos últimos 36 anos. 
794 - Território Café do Cerrado: transformações na estrutura produtiva e seus impactos sobre o pessoal ocupado

Tabela 5. Pessoal ocupado em Minas Gerais e nos municípios do Caccer.

\begin{tabular}{|c|c|c|c|c|c|c|c|}
\hline Localidade & $\begin{array}{c}\text { Descrição/ } \\
\text { anos }\end{array}$ & 1970 & 1975 & 1980 & 1985 & 1995/96 & 2006 \\
\hline \multirow{4}{*}{$\begin{array}{l}\text { Minas } \\
\text { Gerais }\end{array}$} & Total & 1.979 .847 & 2.189 .945 & 2.284 .550 & 2.660 .130 & 2.000 .046 & 1.896 .924 \\
\hline & $\begin{array}{l}\text { Empregados } \\
\text { Permanentes }\end{array}$ & 190.692 & 271.904 & 360.562 & 393.125 & 324.652 & 238.883 \\
\hline & $\begin{array}{l}\text { Empregados } \\
\text { Temporários }\end{array}$ & 291.265 & 320.438 & 428.121 & 502.340 & 304.955 & 402.087 \\
\hline & $\begin{array}{c}\text { Posseiros } \\
\text { (empregados) }\end{array}$ & 201.574 & 148.565 & 142.910 & 139.479 & 65.530 & 15.989 \\
\hline \multirow{4}{*}{$\begin{array}{l}\text { Municípios } \\
\text { do Caccer }\end{array}$} & Total & 178.558 & 202.455 & 218.910 & 270.193 & 194.682 & 198.811 \\
\hline & $\begin{array}{l}\text { Empregados } \\
\text { Permanentes }\end{array}$ & 18.209 & 31.318 & 48.499 & 61.616 & 49.830 & 35.600 \\
\hline & $\begin{array}{l}\text { Empregados } \\
\text { Temporários }\end{array}$ & 24.133 & 30.632 & 36.674 & 60.512 & 26.296 & 57.542 \\
\hline & $\begin{array}{c}\begin{array}{c}\text { Posseiros } \\
\text { (empregados) }\end{array} \\
\end{array}$ & 21.858 & 17.401 & 18.444 & 14.722 & 1.840 & 589 \\
\hline
\end{tabular}

Fonte: Dados dos censos agropecuários MG, FIBGE (1970, 1975, 1980, 1985, 1995/96 e 2006).

No entanto, ao analisar os resultados do censo agropecuário de 2006, notou-se que não houve queda no número total de pessoal ocupado no território do café. Pelo contrário, houve leve acréscimo de 2,12\% nos municípios do Caccer, enquanto no estado, por outro lado, a baixa foi de 5,16\% entre os censos de 1995/96 e 2006.

Para explicar essa situação, foram realizadas entrevistas com experts (lideranças de organizações representativas, empresários, técnicos etc.) da cafeicultura do Cerrado Mineiro. A primeira explicação para a manutenção do nível de emprego naquela cafeicultura foi a quase extinção do número de posseiros dentro dos estabelecimentos entre 1970 e 2006. De um total de 21.858 pessoas ocupadas em 1970, restavam apenas 589 nos municípios pertencentes ao Caccer. Esses posseiros que deixaram suas atividades autônomas passaram a ocupar-se na cafeicultura como trabalhadores assalariados.

A Tabela 6 retrata a taxa anual de crescimento de quatro diferentes formas de ocupação do pessoal, entre as quais se destaca o comportamento dos empregados permanentes e temporários. A taxa de empregados permanentes manteve-se positiva entre 1970 e 1985 no estado de Minas Gerais e nos municípios do Caccer. Nesses municípios, a taxa anual superou a estadual nos três períodos, o que resultou em um salto de 18.209 trabalhadores em 1970, para 61.616 em 1985 (Tabela 5). Entre 1985 e 2006, ocorreu uma queda acentuada nesta taxa para os municípios do Caccer, com 35.600 trabalhadores. Este fato se repetiu no estado, mas em menor intensidade.

Enquanto isso, a taxa de empregados temporários também se manteve positiva entre 1970 e 1985 no estado de Minas Gerais e nos municípios do 
Caccer. Nesses municípios, a taxa anual superou a estadual em dois períodos, com destaque para o período 1980-1985, que resultou em um salto de 24.133 trabalhadores em 1970, para 60.512 em 1985. Entre 1985 e 1995/96, ocorreu uma baixa significativa nessa taxa para os municípios do Caccer e para o estado, respectivamente, de $8 \%$ e 4,87\%. Este fato levou muitos estudiosos a acreditar que a tendência de queda se manteria para o censo de 2006. Entretanto, houve um acréscimo no emprego temporário naquele período, de 8,15\% nos municípios do Caccer e de $2,80 \%$ no estado mineiro.

Tabela 6. Taxa de crescimento do pessoal ocupado em Minas Gerais e nos municípios do Caccer.

\begin{tabular}{|c|c|c|c|c|c|c|}
\hline Localidade & Descrição/anos & $1970-75$ & $1975-80$ & 1980-85 & $\begin{array}{c}1985- \\
1995 / 96\end{array}$ & $\begin{array}{c}1995 / 96 \\
2006\end{array}$ \\
\hline \multirow{4}{*}{ Minas Gerais } & Total & $2,04 \%$ & $0,85 \%$ & $3,09 \%$ & $-2,81 \%$ & $-0,53 \%$ \\
\hline & $\begin{array}{l}\text { Empregados } \\
\text { Permanentes }\end{array}$ & $7,35 \%$ & $5,81 \%$ & $1,74 \%$ & $-1,90 \%$ & $-3,02 \%$ \\
\hline & $\begin{array}{l}\text { Empregados } \\
\text { Temporários }\end{array}$ & $1,93 \%$ & $5,97 \%$ & $3,25 \%$ & $-4,87 \%$ & $2,80 \%$ \\
\hline & $\begin{array}{c}\text { Posseiros } \\
\text { (empregados) }\end{array}$ & $-5,92 \%$ & $-077 \%$ & $-048 \%$ & $-7,28 \%$ & $-13,16 \%$ \\
\hline \multirow{4}{*}{$\begin{array}{l}\text { Municípios } \\
\text { do Caccer }\end{array}$} & Total & $2,54 \%$ & $1,58 \%$ & $4,30 \%$ & $-3,22 \%$ & $0,21 \%$ \\
\hline & $\begin{array}{l}\text { Empregados } \\
\text { Permanentes }\end{array}$ & $11,46 \%$ & $9,14 \%$ & $4,90 \%$ & $-2,10 \%$ & $-3,31 \%$ \\
\hline & $\begin{array}{l}\text { Empregados } \\
\text { Temporários }\end{array}$ & $4,88 \%$ & $3,67 \%$ & $10,53 \%$ & $-8,00 \%$ & $8,15 \%$ \\
\hline & $\begin{array}{c}\text { Posseiros } \\
\text { (empregados) }\end{array}$ & $-4,46 \%$ & $1,17 \%$ & $-4,41 \%$ & $-18,78 \%$ & $-10,77 \%$ \\
\hline
\end{tabular}

Fonte: Dados dos censos agropecuários MG, FIBGE (1970, 1975, 1980, 1985, 1995/96 e 2006).

Como explicar tais fatos, se houve aumento da mecanização? Um conjunto de fatores aponta o aumento da procura por trabalhadores temporários, incluindo o aumento de área de produção.

Assim, viu-se que, de um lado, estava a produção bianual do café, que demandou mais trabalhadores na fase de colheita, mas não influenciou outras atividades de manutenção da cultura, o que não implicaria aumento do pessoal permanente, apenas dos trabalhadores temporários.

Por outro lado, o saldo do processo mecanização ainda é negativo para o emprego permanente. Mesmo que algumas atividades de operação e manutenção desses equipamentos requeiram mão de obra permanente, a quantidade de atividades que os tratores e os equipamentos acoplados mais as colheitadeiras abarcam é suficiente para eliminar milhares de postos de trabalho.

Em uma entrevista com um prestador de serviços de colheita de café em Patrocínio, foi relatada a atuação de dez máquinas em operação. Como cada 
Território Café do Cerrado: transformações na estrutura produtiva e seus impactos sobre o pessoal ocupado

máquina exige, pelo menos, três operadores por dia (oito horas cada), mais doze trabalhadores para suporte geral no período de prestação dos serviços, isso totaliza pelo menos 42 trabalhadores. Porém, o número de trabalhadores permanentes, aqueles que ficam o ano todo na firma desempenhando outras funções, não ultrapassa 15 , o que quer dizer que quase $2 / 3$ são contratados no início da colheita e demitidos logo após o seu término. Situação semelhante ocorre nas grandes propriedades que adotam a colheita mecanizada com frota própria.

O emprego gerado pelas empresas prestadoras de serviços tem outra característica importante: pelo fato de as sedes dessas empresas estarem localizadas nas cidades, o emprego gerado acaba sendo contabilizado como urbano, embora a atuação ocorra no campo. Como o censo agropecuário visita o estabelecimento rural, essa parte do pessoal ocupado, embora seja no campo, não é contabilizada, bem como outras atividades de prestação de serviços.

Com o avanço da mecanização, as atividades braçais continuam reduzindo; assim, o proprietário, ou o seu gerente, com os devidos equipamentos, realizam diversas atividades antes desempenhadas por trabalhadores em geral (manutenção e aplicação de tratos culturais à lavoura de café, por exemplo). O resultado é a eliminação de vários postos de trabalho permanentes e demanda de alguns temporários.

Também é importante lembrar o papel de pequenos agricultores nessa região, inclusive, na atividade cafeeira. Os dados do censo de 2006 mostram que os números de estabelecimentos em Minas Geriam cresceram novamente, voltando ao patamar de 1985 (Tabela 7). Ou seja, de 1995/96 para 2006, houve incremento de 54.940 estabelecimentos no estado, padrão repetido em boa parte dos municípios do Caccer. A microrregião de Patrocínio teve seus estabelecimentos acrescidos em 804 unidades, passando de 8.384 em 1995/95, para 9.193 em 2006, acréscimo de 9,65\%.

Tabela 7. Número de estabelecimentos rurais no estado de Minas Gerais.

\begin{tabular}{ccccccc}
\hline \multirow{2}{*}{ Anos } & \multicolumn{7}{c}{ Censos } \\
\cline { 2 - 7 } & $\mathbf{1 9 7 0}$ & $\mathbf{1 9 7 5}$ & $\mathbf{1 9 8 0}$ & $\mathbf{1 9 8 5}$ & $\mathbf{1 9 9 5 / 9 6}$ & $\mathbf{2 0 0 6}$ \\
\hline Estabelecimentos & 453.998 & 463.515 & 480.631 & 551.488 & 496.677 & 551.617 \\
\hline
\end{tabular}

Fonte: Dados dos censos agropecuários MG, FIBGE (2006).

Assim, o impacto sobre o pessoal ocupado é significativo, pois o que se verifica em muitas propriedades de café, sobretudo para pequenos e médios produtores, é a fixação de residência nas cidades da região com a manutenção de seu estabelecimento agrícola administrado em tempo parcial. Nesse sentido, esses produtores mantêm a sua lavoura com o trabalho próprio, uma vez que culturas permanentes como a cafeeira não demandam trabalhos contínuos. 
Nos momentos em que a atividade requer maior força de trabalho, o produtor contrata trabalhadores temporários sem a necessidade da contratação de trabalhadores permanentes.

Estes pequenos produtores geralmente não têm condições de investir em máquinas para executar suas atividades e, em muitos casos, a propriedade é tão pequena que não compensa o deslocamento de máquinas dos prestadores de serviço, como é o caso da colheitadeira de café que, para ser levada até uma propriedade, exige uma área mínima para entrar em operação ${ }^{19}$. Além disso, boa parte dessas propriedades encontra-se em terrenos de declividade acentuada, inviabilizando o uso de máquinas colheitadeiras.

De maneira geral, entretanto, de acordo com técnicos da Associação dos Cafeicultores da Região de Patrocínio (Acarpa), a intenção dos produtores da região é de continuar a mecanização na colheita do café, pois esse tipo de colheita apresenta muitas vantagens em relação ao trabalho manual, o que ampliará o impacto sobre o pessoal ocupado.

Portanto, não podem ser desconsideradas conclusões anteriores de Ortega, Jesus e Mouro (2009) quanto ao impacto sobre o pessoal ocupado e suas repercussões em diversas regiões do território nacional. Esses trabalhadores temporários, em grande medida, são oriundos de regiões de economias deprimidas, particularmente de Minas Gerais e da região Nordeste.

\section{Considerações finais}

Espera-se haver demonstrado, neste artigo, a consolidação da cafeicultura do Cerrado Mineiro ao longo das últimas três décadas, o que significou dar grande destaque à produção da região no contexto estadual e nacional. Com apenas 4,65\% dos estabelecimentos de Minas Gerais, a região produziu 20,14\% do café tipo arábica no estado, que responde por $65 \%$ da produção do país, de acordo com dados do censo agropecuário de 2006. Assim, os 55 municípios do território do café produziram, em 2006, mais de 4,1 milhões de sacas de café, alcançando receita de cerca de R\$ 1,2 bilhão na produção do café arábica.

A elevada produção e a produtividade da região foram consequência de uma série de inovações tecnológicas aplicadas ao processo produtivo. Inovações biológicas, físico-químicas, agronômicas e mecânicas que, no seu conjunto,

19 Alguns proprietários de empresas prestadoras de serviço de colheita de café afirmaram, em entrevista, que a área mínima para o deslocamento de suas máquinas é de 10 hectares, quando a máquina está próxima da propriedade. Caso a máquina esteja longe, não é viável o deslocamento para a colheita em pequenas áreas, pois o custo de deslocamento é alto. 
Território Café do Cerrado: transformações na estrutura produtiva e seus impactos sobre o pessoal ocupado

modernizaram o processo produtivo da região com forte impacto sobre o pessoal ocupado nos estabelecimentos agrícolas.

A ocupação de pessoal nessa região passou por momentos distintos. Em um primeiro momento, entre os anos 70 e início dos 90, enquanto a cultura cafeeira esteve em franco crescimento extensivo, houve forte geração de novos postos de trabalho. No entanto, no início dos anos 90, com a modernização de diversas máquinas e equipamentos, especificamente aqueles voltados para a colheita, constata-se a queda expressiva do pessoal ocupado.

Entretanto, fruto de uma série de desdobramentos, o censo agropecuário de 2006 não registrou continuidade da queda no número de pessoal ocupado, conforme se esperava. Ao contrário, houve leve acréscimo nos municípios do Caccer, especificamente entre os trabalhadores temporários e os da agricultura familiar. O crescimento do pessoal temporário se deu apesar do avanço da mecanização, que limitou drasticamente o conjunto de atividades de manutenção da cultura cafeeira, reduziu a demanda por trabalho permanente e exigiu mais trabalhadores em períodos específicos, como no auxílio à colheita mecanizada, ou seja, muitos são trabalhadores especializados, mas não são contratados permanentemente.

Além disso, por meio dos dados censitários, foi possível observar que o tamanho médio dos estabelecimentos agropecuários, particularmente no caso das lavouras permanentes nos municípios do Caccer, supera o tamanho médio das áreas encontradas em Minas Gerais e no Brasil. Isso também foi verificado entre as propriedades de agricultura familiar. Ou seja, a cafeicultura do Cerrado Mineiro possui um tamanho de propriedade superior ao verificado em outras regiões.

Também é preciso ampliar a base de coleta de dados dos censos agropecuários, pois a dinâmica agropecuária passa por grandes transformações e, cada vez mais, ocorre maior interação entre os centros urbanos e as atividades produtivas do campo. Como exemplo desta interação, devem ser incluídas nas visitas censitárias as empresas prestadoras de serviço para o meio rural, pois, na região do café, é significativo o estoque de máquinas para colheitas, bem como o de outros equipamentos que estão nas sedes das empresas nos centros urbanos e prestam serviços nos estabelecimentos rurais. Isso mascara qualquer análise de modernização do campo e seus impactos, se desconsiderarmos tais máquinas e equipamentos.

Ressalta-se, portanto, importantes transformações ocorridas no Cerrado Mineiro, particularmente na cafeicultura. No entanto, essas conclusões não permitem apontar uma tendência para o futuro, que irá depender de desdobramentos que os atores locais vão desempenhar nos próximos anos. $\mathrm{Ou}$ seja, vai depender das inovações tecnológicas aplicadas à atividade, que vêm sendo bastante disseminadas por organismos de pesquisas que atuam na região. 


\section{Referências bibliográficas}

CERVO, A. L.; BERVIAN, P. A. e DA SILVA, R. Metodologia Científica. 6ạed. São Paulo: Pearson Prentice Hall, 2007. 162 p.

CRUZ NETO, F.; MATIELLO, J. B. Estudo comparativo de rendimento de colheita entre cultivares Mundo Novo e Catuaí, em lavouras com diferentes níveis de produtividade. In: CONGRESSO BRASILEIRO DE PESQUISAS CAFEEIRAS, 9., 1981, São Lourenço. Anais... Rio de Janeiro: MA/PROCAFE, 1981. p. 329-333.

FARINA, E. M. M. Q. Reflexões sobre desregulamentação e sistemas agroindustriais: a experiência brasileira. São Paulo, FEA/USP, 1996, 150 p.

GARLIPP, A. A. B. P. D. Mecanização e emprego rural: os casos do café e da canade-açúcar no Triângulo Mineiro e Alto Paranaíba (MG). Uberlândia. 1999. 111 p. Dissertação (Mestrado Desenvolvimento Econômico) - Universidade de Uberlândia, Uberlândia, 1999.

GRAZIANO da SILVA, J. Tecnologia e agricultura familiar. Porto Alegre: Ed. da UFRGS, 1999. 238 p.

IBGE - Censos Agropecuários MG. Edições de 1970, 1975, 1980, 1985, 1995/96 e 2006. Rio de Janeiro/RJ.

JESUS, C. M. A terceirização na agricultura do Cerrado Mineiro: a mecanização da colheita do café. Monografia de conclusão de curso. Instituto de Economia, Universidade Federal de Uberlândia, 2003.

JORNAL O ESTADO DE SÃO PAULO. Caderno de Economia. Ano 127, no 41060 - 19 de março de 2006.

LAURENTI, A. C. Terceirização dos trabalhos agrários e o "novo rural". ORNAs, ocupações rurais não-agrícolas: anais: oficina de atualização temática. Londrina, PR: IAPAR, 2000.

MINISTÉRIO DO TRABALHO E EMPREGO. Cadastro geral de empregados e desempregados (CAGED)-Perfil do estabelecimento, 1997-2005.

ORTEGA, A. C.; GARLIPP, A. A. D.; JESUS, C. M. Terceirização e emprego rural na agricultura do cerrado mineiro: os casos da mecanização no café e na cana-de-açúcar. XLI Congresso da Sober, Juiz de Fora, Julho de 2003.

ORTEGA, A. C. Agronegócios e representação de interesses no Brasil. EDUFU. Uberlândia, 2005.

ORTEGA, A. C. e JESUS, C. M. Café do Cerrado: Certificação de origem, nova sociologia econômica e desenvolvimento territorial rural. In: XIV Encontro 
Território Café do Cerrado: transformações na estrutura produtiva e seus impactos sobre o pessoal ocupado

Nacional de Economia Política, 2009, São Paulo. Anais do XIV Encontro Nacional de Economia Política. São Paulo, SEP, v. 1 p. 1-16.

PESSOA, V.L.S. Ação do Estado e as transformações agrárias no cerrado das zonas de Paracatu e Alto Paranaíba. Rio Claro, UNESP, 1989. (tese de doutorado)

SALIM, C. A. As políticas econômicas e tecnológicas para o desenvolvimento agrário das áreas de cerrado no Brasil: avaliação e perspectivas. In: Cadernos de Difusão de Tecnologia. Brasília, 3(2), mai-ago, 1986.

REVISTA CAMPO ABERTO. Ano 19, nํำ1. Massey Fergusson. Fevereiro de 2005. REVISTA PANORAMA RURAL. Ano IV, no58 - dezembro 2003.

RIBEIRO, A. E. A modernização dos cerrados. Belo Horizonte, CPT-MG, 1985. (mimeo)

SILVA, F. M.; CARVALHO, G. R.; SALVADOR, N. Mecanização da colheita do café. Informe Agropecuário, EPAMIG, v. 18, no 187. 1997 .p. 43-54.

SILVA, F. M.; SALVADOR, N. Mecanização da lavoura cafeeira. Lavras: UFLA, 1998. $55 \mathrm{p}$.

SAES, M. S. M. A racionalidade econômica da regulamentação no mercado brasileiro de café. FEA/USP, 1995. (Tese de Doutorado).

SALIM, C.A. As políticas econômicas e tecnológicas para o desenvolvimento agrário das áreas de cerrado no Brasil: avaliação e perspectivas. In: Cadernos de Difusão de Tecnologia. Brasília, 3(2), mai-ago, 1986.

Vocabulário Ortográfico da Língua Portuguesa / Academia Brasileira de Letras. 5a ed. São Paulo: Global, 2009. 